\title{
Robert Oresko
}

\section{The Question of the Sovereignty of Geneva after the Treaty of Cateau-Cambrésis}

The Treaty of Cateau-Cambrésis, signed on 2 and 3 April 1559, concluded nearly four decades of open conflict between the House of Habsburg, as represented by the Emperor Charles V and his son King Philip II of Spain, and two consecutive Valois kings of France, François I and his son and successor, Henri II. Although it was the clauses of the treaty regulating the relations between the two preponderant dynasties of mid-sixteenth-century Europe which attracted most contemporary comment, the principal individual beneficiary of the accord was neither a Habsburg nor a Valois, but, rather, the head of the House of Savoy, the young Duke Emanuele Filiberto (1528-1580). The treaty provided for the restoration to Emanuele Filiberto of many of the patrimonial lands in the duchy of Savoie and the principality of Piedmont ${ }^{1}$ which, during the reign of his father, Duke Charles III, had been occupied by the forces of his close kinsmen ${ }^{2}$, Charles $\mathrm{V}$ and François $\mathrm{I}^{3} .1536$ had marked the nadir of the political fortunes of the House of Savoy. The French invasion of the exposed duchy of Savoie, the prelude to their penetration into Piedmont, and the swift conquest of all the dynasty's lands in the Suisse Romande, including the entire Pays de Vaud, by the canton of Bern, forced Charles III into an internal exile at Vercelli. Habsburg occupation of those parts of the principality of Piedmont essential for the defense of the duchy of Milan, presented by Charles V as a beneficent gesture to Charles III which aimed at blocking further French advances, ensured that a Savoyard restoration would depend upon the resolution of the difficulties between both of the major powers. Upon Charles III's death in 1553, his only surviving child, Emanuele Filiberto, became head of the House with effective authority over only scattered remnants of his patrimony. From 1545 Emanuele Filiberto had entered the service of his maternal uncle, Charles $\mathrm{V}$, and throughout the 1550 s assumed increasing responsibility in the Habsburg system, reaching his military apogee as the architect of the victory at Saint-Quentin in

${ }^{1}$ In this paper, 'Savoie' refers to the duchy with its capital at Chambéry, located to the west of the Alps, while 'Savoy' refers to the dynasty and to the aggregate of its holdings, principally the duchy of Savoie, the principality of Piedmont, of which Turin was the capital, and the county of Nice. I have used 'Helvetic confederation' for the 'louable corps helvétique' to avoid the anachronistic 'Switzerland'.

${ }^{2}$ Charles III's elder half-sister, Louise of Savoy, was the mother of François I; Charles III's wife, Beatrice of Portugal, was the sister of Charles V's consort, the Empress Isabella.

${ }^{3}$ J. Dumont, Corps universel diplomatique ..., vol. IV (Amsterdam and The Hague 1728) 39. 
1557. The interval between the French defeat and the final signature of the Treaty of Cateau-Cambrésis made clear that a Savoyard restoration would be incorporated into the agreement between Habsburg and Valois, with both powers withdrawing their troops, but the French retaining five fortresses, including that at the capital of Piedmont, Turin, the Habsburgs two. As Emanuele Filiberto's association with Habsburg policy had been intimate, a further accommodation with the duke's Valois cousins was offered in the person of Henri II's only surviving sister, Marguerite de France, duchesse de Berri. The date of the marriage of Emanuele Filiberto and Marguerite was moved ahead at the insistence of Henri II, lying mortally wounded by Montgomery's lance, and was performed ( 9 July) the evening before the king died.

But the restoration of Emanuele Filiberto was, at best, only a partial one. Not only did the Valois and the Habsburgs retain a military presence in those lands returned to the duke, but a number of important dynastic claims were left either unsatisfied or unresolved by the treaty: the possession of the marquisate of Monferrato and that of Saluzzo and the re-integration of the House of Savoy into the lands around Lake Geneva which had been lost in 1536 . The last question touched directly the canton of Bern and the city with which it had entered a combourgeoisie, Geneva, the spiritual centre of the Calvinist reformation. Progress towards the agreement of Cateau-Cambrésis had been monitored with great attentiveness by the councils of both cities; for the restoration of Emanuele Filiberto to his transalpine patrimony, however hedged in it was by conditions, re-introduced into the policies of both Bern and Geneva an element which had been absent for nearly a quarter of a century, the presence of the Catholic House of Savoy immediately to the south. The acquisition of Emanuele Filiberto as a close neighbour alone would have alarmed Bern and Geneva, in view of his public devotion to the Church of Rome and his proven prowess as a military commander; but the assumption that the duke would proceed to press claims aimed ultimately at reversing the situation resulting from his father's defeats in 1536 deepened fears and anxieties in both cities. The Council of Geneva, unendowed with the territories, revenues and military apparatus of the canton of Bern, saw its position as particularly vulnerable.

From the end of January to the end of March 1536, Bernese troops had overrun all of the Savoyard lands in the Pays de Vaud and the Pays de Gex; they were joined in this occupation of Charles III's holdings around Lake Geneva by the canton of Fribourg and by the Valaisans, who took possession of the Chablais. Emanuele Filiberto, on his restoration, accorded a high priority to the return of his House into the Vaud, and it was observed in Geneva in 1562 that "depuis la paix faite entre les Princes, le duc de Savoie a tâché par plusieurs moyens d'entrer en voie d'appointement avec eux [i.e. the Bernese] sur les différends qu'ils ont ensemble à cause du pays conquis ..." 4". In fact, Emanuele Filiberto had sent a secret envoy to Bern as early as $1553^{5}$. The account

\footnotetext{
4 Archives d'état, Genève (hereafter AEG), Registres du Conseil (hereafter R.C.), vol. 57, fol. $134 \mathrm{r}$. I have modernised the spelling in my own transcriptions from archival sources, but I observe whatever spelling is adopted by other scholars when citing their printed transcriptions.

${ }^{5} \mathrm{~J}$. Cart, Le traité de 1564 et la rétrocession au duc de Savoie du Chablais et du Pays de Gex, in: Revue d'histoire vaudoise VIII (1900) 181.
} 
presented to the Council of Geneva in 1562 by Michel Roset, the citizen most frequently entrusted with implementing the city's diplomatic policy, underscored the sense of threat which the Treaty of Cateau-Cambrésis induced in the citadel of Calvin: „Estant la paix des deux Roys de France et Hespagne conclue au mois d'apvril, les bruits en couroient avec plusieurs advertissements d'entreprises contre la ville sus la restitution des pays au Duc de Savoye ..." ${ }^{\text {“6 }}$ No later than August 1559, Emanuele Filiberto had established contact with the canton of Bern and had suggested a meeting at Neuchâtel to discuss a treaty of peace and alliance ${ }^{7}$. Certainly from a very early date Bern seems to have indicated, at least implicitly, that it was prepared to accept some of the duke's claims and that for a variety of judicial and political reasons it viewed a form of restitution to the House of Savoy as inevitable. A preparedness to give weight to dynastic claims which touched the occupied territory, especially when those demands were backed by the bulk of French royal patronage, had been signalled as early as 1547, when the House of Luxembourg-Martigues, a collateral branch of the extinct imperial dynasty, acquired from Bern, with the active support of François I, restitution of three of its holdings in the Vaud. The restoration was especially striking as the Luxembourg-Martigues were tied to the House of Savoy by at least five marriages contracted during the second half of the fifteenth century ${ }^{8}$ and were even more intimately linked to Charles III and Emanuele Filiberto through the House of Bresse-Bretagne. Recognition of ducal rights in the Vaud did not, however, bring the immediate return of Emanuele Filiberto to the Suisse Romande, and the final agreement between the House of Savoy and the canton of Bern was not implemented until 1567. Negotiations between Bern and Turin were persistently complicated by the intersecting question of the nature of the relationship between the House of Savoy and the city of Geneva, a densely tangled jungle of conflicting rights and privileges which made the return of some lands held solely by right of conquest seem relatively straightforward by comparison.

It has become a commonplace of Genevan history to see within the first forty years of the sixteenth century the unfolding of a double revolution', a religious revolution, the Reformation, which had been preceded and aided by the political revolution which had given exclusive civic and judicial power to the aggregate of syndics and members of the Small Council and the Council of the Two Hundred popularly known as the seigneurie de Genève or Messieurs de Genève. This monopoly of political authority within Geneva had been acquired at the expense of the prince-bishop of Gen-

${ }^{6}$ Michel Roset, Les chroniques de Genève, ed. Henri Fazy (Geneva 1894) 428: C. 48; (hereafter Roset).

${ }^{7}$ Amédée Roget, Histoire du peuple de Genève (Geneva 1870-1883) vol. V, 261; (hereafter Roget).

8 Olivier Dessemonter, Les Luxembourg-Martigues, seigneurs au Pays de Vaud, 1487-1558, in: Zeitschrift für schweizerische Geschichte IV (1954) 111-112. The Council of Bern parried a request of 1540 by François I for a consideration of François de Luxembourg's rights with the observation "que ledit seigneur viconte et (sic) prochain en lignaige au duc hors de Savoye, lequel est encore notre ennemys ..." (107).

9 William Monter, De l'évêché à la Rome protestante, in: Histoire de Genève, ed. P. Guichonnet (Toulouse 1974) 133. 
eva and of the House of Savoy. As with so much in early modern Europe, the distribution of power in pre-revolutionary Geneva was customarial, ill-defined and fluid. The House of Savoy based much of its position in Geneva upon the possession of the vidomnat, an office held as a fief of the prince-bishop, which the head of the House had first occupied towards the end of the thirteenth century. The vidomne had wide-ranging and not always precisely delineated responsibilities for the judgement of both civic and criminal case ${ }^{10}$ and from this post, which, when viewed in terms of the strictest legal precision, was inscribed within formidable limitations, the House of Savoy attempted to extend its juridical authority within the city. The distinction between the justice offered by the prince-bishop and that of his ducal vidomne had become very blurred during the pontificate of the anti-pope Felix V, previously Duke Amadeus VIII of Savoy, who held the bishopric of Geneva until his death in 1451. His successors as bishops were either cadets of the House of Savoy or trusted clients, and the de facto power of the dukes of Savoy within Geneva grew with subsequent decades of familial cooperation between the diocesan authorities and the Savoyard court. Resistance by the Genevan seigneurie to Charles III's claims of ultimate sovereignty over the city manifested itself in a sequence of confrontations during the $1520 \mathrm{~s}$, focussing upon the competence of the Council to enter into alliances of combourgeoisie with cantons which were part of the Helvetic confederation without the consent of the duke. These disputes led to the decisive events of 1536. The collapse of Charles IIl's political and military position and the withdrawal of the last resident bishop, Pierre de La Baume, in $1533^{\prime \prime}$, removed any significant competition to the civic bodies and defined a power vacuum of much greater extent than had been previously imagined, into which the seigneurie moved with concentrated swiftness. In 1536, the register of the Council noted assertively that „Nous resterons princes dans notre ville" ${ }^{\prime 2}$.

Such forthright expressions of independent sovereignty discouraged the ambitions of Geneva's neighbours, who fully appreciated the special geo-political position of the city. The view expressed in the 1584 treaty of alliance between Zürich, Bern and Geneva that „la prosperité de toute la louable communauté des Ligues étant une ville de Genève reconnue pour clef de pays et commode passage "13 must have been held at least as early as the $1530 \mathrm{~s}$, when both François I and the canton of Bern, taking advantage of the removal of the prince-bishop and the duke, suggested their substitution as Geneva's ultimate sovereign. These tentatives were successfully resisted by the seigneurie, although the 1536 perpetual alliance with Bern gave that canton the right to regulate Geneva's relations with the outside world. Protected by both the combourgeoisie and the perpetual alliance with Bern, the seigneurie of Geneva did indeed behave as its own sovereign prince, regulating the procedure for the elections to the councils and

${ }^{10}$ Henry Grandjean, De la féodalité à la communauté. Histoire de Genève dès origines à 1798 (Geneva 1951) 107.

${ }^{11}$ François Perron and Georges Grandchamps, Les évêques de Genève-Annecy (Annecy 1959) 25. This is vol. VII of the journal Annesci.

${ }_{12}$ Monter, De l'évêché à la Rome protestante, 129.

${ }^{13}$ Archives du ministère des affaires étrangères, Paris, Correspondance politique: Genève, vol. I, fol. 13. 
assuming such traditionally regalian rights as coining money. The edicts of 1543 , which, significantly, remained unpublished until $1890^{14}$, codified the organisation of authority within the city, confirming practices, as William Monter observes, which had already been established ${ }^{15}$. Geneva in the 1530 s, 1540 s and 1550 s was no stranger to internal factional strife of both a religious and political nature, but its relative security from any external threat during these decades was a factor of the very first importance in the evolution of a stable procedure for governing and in the consolidation of Calvin's reformation.

It was precisely this sense of security which the Treaty of Cateau-Cambrésis shattered. The distinction between the exercise of sovereign power and the justification of the possession of such power had been ignored by the seigneurie during the period when there were no rival claimants; the edicts of 1543 deal with the functional structure of the government, not with the nature of the Genevan state. The restoration of Emanuele Filiberto meant that the seigneurie of Geneva's assumption of sovereignty, in default of the prince-bishop and the duke of Savoy, would be challenged by an arsenal of arguments largely composed of inherited, dynastic rights. Geneva soon found itself under pressure from an unexpected quarter to produce its own set of juridically recognised rights to sovereignty to match against those emanating from the ducal chancellery; for the determination of Emanuele Filiberto to retrieve as much of his House's position within Geneva as possible was complemented by Bern's resolve to reach an accord with Turin in order to minimise the possibility of strife within the Helvetic confederation, the Catholic members of which had reached varying forms of alliance with the restored duke. The problem of Geneva was a major obstacle to the conclusion of any accord between Emanuele Filiberto and the Protestant cantons. For three decades Geneva had not needed to concern itself with the bases of its sovereignty; from 1559 , faced with the re-assertion of the pretentions of the House of Savoy and under pressure from Bern, Geneva's only ally, to help defuse the potentially dangerous conflict of claims, the seigneurie was confronted with demands to justify the juridical nature of a sovereignty which had been achieved as a result of military and political crises. In the diplomatic correspondence of the Genevan councils from the Treaty of Cateau-Cambrésis of 1559 until the conclusion in 1570 of a mode de vivre with Emanuele Filiberto one can measure the problems confronting what historians of subsequent centuries have almost universally viewed as a revolutionary, early-modern 'republic', the city of Geneva struggling with the problems of its own legitimacy, with questions of justificatory documentation and definitions of the nature of the state itself.

Initially, it was not the weight of Savoyard legal arguments which was feared in Geneva, but rather the prospect of direct military intervention by the Catholic powers resolved to impose Emanuele Filiberto upon the city as prince and to topple the edifice of the Calvinist church. The accidental death of Henri II lessened this menace, and Philip II's reluctance to participate in a campaign so close to some of his own pat-

${ }^{14}$ Henri Fazy, Les constitutions de la république de Genève (Geneva and Basel 1890) 48-57, especially $48, n$. 1 . The text of the edicts is published as an appendix, 287-335.

19 William Monter, Calvin's Geneva (New York 1967) 72. 
rimonial lands manifested itself at an early date. The duque de Alba, at the French court in June 1559 to conduct the king's third bride, Elisabeth de Valois, to Spain, wrote to Philip II that "En lo de Geneva lo quise acudirle al camino que el [the connétable, Anne de Montmorency] mostrava, porque no me parecio convenir al servicio de V. M. dalles prenda con que ellos podiessen dezir en ningun tiempo que V.M. quisiesse hazer empresa contra Esquiçaros “16. About one year later, the Cardinal de Granvelle echoed these cautionary tones: „yo no puedo creer que en este tiempo mueva las cosas, segun le [Emanuele Filiberto] he oydo hablar muchas vezes, quando en esto de Geneva, despues de las pazes, he discurrido con él, con quanto sé que los suyos continuamente le solicitan sobre ello, mas lo que le cumple es establecerse ántes que mover ninguna cosa, y me acuerdo muy bien que lo de Geneva fué causa primera de hachar á su padre fuera de sus estados." ${ }^{17}$ Despite such wariness on the part of the Habsburgs, the fear in Geneva of Catholic force majeure was the background against which the diplomatic manouvring of the 1560 s was played, and on 14 January 1560 the council noted rumours that Savoy might 'faire quelque surprise' ${ }^{18}$. Lucien Cramer's magisterial work catalogues meticulously every diplomatic gesture among the courts of Turin, $\mathrm{Pa}$ ris, Madrid and Rome which could possibly be construed as having had the armed conquest of Geneva as its goal ${ }^{19}$. But to read Emanuele Filiberto's policy exclusively in terms of a preference for a military solution and the quest for outright sovereignty that such an approach could have produced is to underestimate dangerously the caution and flexibility of the duke's treatment of the complex problems which confronted him upon his return to Piemont. The necessity to reconstruct almost every element in a state which had been occupied for over two decades placed obvious practical limitations upon the duke's freedom of action; a military enterprise against Geneva could have been undertaken only with the consent and cooperation of the major Catholic powers. Emanuele Filiberto certainly encouraged such projects when he thought they might receive a favourable audience, and he greeted such suggestions emanating from successive popes with enthusiasm. At the same time, he declined to abandon his policy of attempting to reach a negotiated agreement which would result in the re-establishment of at least a Savoyard presence in Geneva. Both tactics were followed at the same time.

Many of the Leitmotiven which thread their way through the diplomatic exchanges leading up to the 1570 mode de virre made early appearances in the correspondence of the principals. The reply of the Council of Geneva to the offer of assistance from Franz Heinrich of Braunschweig-Lüneburg, on an incognito visit late in 1559, expressed at an early date the reluctance of the city to take any position and a preference to wait

${ }^{16}$ Mignet, Lettres de Jean Calvin ... troisième article, in: Journal des Savants (March 1857) $171-172, \mathrm{n}$. 2. The role of Montmorency is interesting in view of his link, through his wife Madeleine de Savoie-Tende, to Emanuele Filiberto. Emanuele Filiberto inserted the legitimised Savoie-Tende into the succession to the Savoyard throne shortly after his restoration.

${ }^{17}$ Papiers d'état du Cardinal Granvelle, ed. C. Weiss, vol. VI (Paris 1846) 103.

${ }^{18}$ AEG, R. C., vol. 55, fol. 175 r.

${ }^{19}$ Lucien Cramer, La seigneurie de Genève et la maison de Savoie, vol. I (Geneva and Paris 1912) passim. 
upon events: „les seigneurs, l'ayant remercié de son humanité, se contentoient de leur petitesse, estimans leur estre plus séant de suyvre, quand les plus grands auroient pris quelque bon conseil, que de s'avancer par trop. ${ }^{\text {"20 }}$ A sequence of informal approaches from Emanuele Filiberto to Geneva outlined, in very broad and unspecific terms, the arrangement which the duke hoped to achieve by negotiation. In September 1559, well before Emanuele Filiberto had even entered Turin, the comte de Viry was despatched by the duke to Geneva with the reassuring message that he „n'avait qu'autre vue que de s'entendre là-dessus avec la Ville à l'amiable, de la laisser dans la possession tranquille de ce qui lui appartenait, et de lui donner même une beaucoup plus grande étendue de terres que celle qu'elle possédait ${ }^{\text {“21 }}$.

Such a formula left open the question of what precisely the duke thought belonged to the city, and the seigneurie was quick to react to an omission which stood at the heart of the difficulties between Geneva and Savoy. "Quoique le comte de Viry ne parlât pas positivement de la souveraineté de la Ville“22, one of the members of the Council, Michel de l'Arche, sharply informed the envoy "que pour la souveraineté et la parole de Dieu, nous y mettrions nos vies“23. The issue of the sovereignty of Geneva thus entered discussions almost immediately, but, as was to become clear in subsequent negotiations, the word was from time to time defined differently by both parties.

A clearer and more detailed view of Emanuele Filiberto's hopes for the future was presented by his second emissary, Louis Alardet, the recently-elected Bishop of Mondovì. Alardet, who had passed part of his youth in Geneva, noticed that „votre ville était dépeuplée et appauvrie d'hommes et d'autres richesses, sentant votre faiblesse, vous allâtes rechercher les alliances et faveurs de vos voisins, qui vous ont été de grande dépense, et, à mon avis, de petit profit ... promenant par cette ville, laquelle j’ai vu si florissante, et voyant une si fâcheuse mutation, certes, mon coeur s'est attendri, et les larmes plus d'une fois m'en sont venues à l'oeil ..."24. The duke reserved the warmest affection for Geneva, although he was aware, according to an anecdote of Alardet which anticipated Granvelle's observation, „que la ville de Genève ayant été la prem-

${ }^{20}$ Roset, 433: C. 52 bis.

${ }^{21}$ Jean-Antoine Gautier, Histoire de Genève des origines à l'année 1691, eds. A. Cartier and J. Mayor (Geneva 1896-1911) vol. IV, 280; (hereafter Gautier). Jean-Antoine Gautier (1674-1729) was professor at the Académie de Genève and later secrétaire d'état of Geneva. Taking advantage of the ordering of the Genevan archives, started in 1699, Gautier began writing in 1708, requiring the special permission of the seigneurie to carry his research beyond 1565 . Gautier's work is one of the monuments of eighteenth-century historical scholarship and a detailed comparison of his text with the registers of the Council reveals divergences in only one major area. Gautier's attachment to Genevan 'republicanism', manifested clearly in much of his other work, led him to interpolate the word 'republic' into many paraphrases of register entries in which it did not appear. Apart from this caveat, his work has yet to be superseded as a political, as opposed to religious, history of Geneva in the sixteenth and seventeenth centuries.

${ }^{22}$ Ibid., vol. IV, 280.

${ }^{23}$ Roget, vol. VI, 3.

${ }^{24} \mathrm{~J}$. Gaberel, Une escalade diplomatique, in: Bibliothèque universelle III (1858) 580-581. Gaberel reproduces the entire text of Alardet's letter to Emanuele Filiberto on his mission to Geneva. This letter, in French, is in the Archivio di Stato, Turin. 
ière source et l'origine de la perte des Etats de feu monseigneur mon père, et par conséquence [est] la cause des maux qui s'en sont suivis ..." ${ }^{\text {"25 }}$. Alardet's solution, presented ingenuously as an afterthought, was simple and straightforward: ,j'avais pensé, s'il vous plaisait de recevoir en cette votre cité, et l'accepter [Emanuele Filiberto] pour votre prince, avec la dignité et autorité que Messeigneurs ses ancêtres y ont eue, sans rien diminuer de vos franchises, libertés, prérogatives et immunités, à votre avis, ne serait-ce pas le véritable et souverain remède à toutes vos calamités ... Son Altesse ferait sa résidence en cette cité, et Madame aussi. Toute leur étude serait de la faire florissante, riche et opulente. “26 Alardet urged a Genevan deputation to visit Emanuele Filiberto, then at Nice, to congratulate him on his restoration and assured the Council that it need have no fears about the preservation of the existing religious settlement should it choose to follow the bishop's advice. The seigneurie resorted, as it was to do frequently, to the smallness of the size of the city in order to excuse itself from the embassy of felicitation, and, as for the sovereignty, Alardet reported to Emanuele Filiberto, „ils me dirent qu'ils avaient choisi Dieu éternel pour leur souverain et seul prince ... que Dieu était plus puissant, plus juste et meilleur Seigneur que vous: c'est pourquoi ils étaient déterminés et résolus de n'obéir à nul aucun prince qu’à Dieu tout seul $^{\text {“27 }}$. Responsibility to God alone was, of course, the purest form of sovereignty in early modern Europe; even Free Imperial Cities and electors of the Empire were, juridically, answerable to the Emperor, who, in turn, was responsible to God. But although the theme of Geneva as a city of whom the prince was God made frequent appearances in the political rhetoric of the debate, its simple statement could not, by definition, address itself to the question of Geneva's right to such a position, especially in view of the claims of other parties to the sovereignty of the city.

Alardet's visit, however, outlined Savoyard proposals. Geneva would preserve all its rights, liberties and privileges and be restored to the enjoyment of great economic prosperity, a reference to the fairs of Geneva which had attracted wealth to the city in the early fifteenth century ${ }^{28}$. The price for this was the acceptance within the city of Emanuele Filiberto. The elision by Alardet of the concept of the rights belonging to the duke's ancestors and the proposal to receive him as prince points to a definition of sovereignty which implied not the incorporation of Geneva into the Savoyard patrimony, and, hence, government imposed from Turin, but rather to the recognition of Emanuele Filiberto as imperial vicar. The imperial vicariate, confirmed in 1365 by the Emperor Charles IV, permitted the House of Savoy "to exercise in the name of the emperor full appellate jurisdiction over lay and ecclesiastical tribunals located within

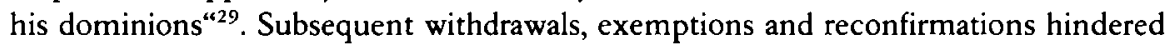
the consistent application of the grant, and as late as the eighteenth century relations between the courts of Turin and Vienna were clouded by jurisdictional disputes. As

25 Ibid., 582.

${ }^{26}$ Ibid., 582-583.

27 Ibid., 586.

${ }^{28}$ Jean-François Bergier, Genève et l'économie européenne de la Renaissance (Paris 1963).

${ }^{29}$ Eugene Cox, The Green Count of Savoy (Princeton 1967) 194. 
the debate over Savoyard restitutions developed in the 1560 s, the claim to the imperial vicariate over Geneva, along with that to the vidomnat within Geneva, both intimately involved with the application of justice, became the two pylons upon which Emanuele Filiberto constructed his claim to ultimate sovereignty over the city. Even after Alardet's visit, however, the precise delineation of what the duke assumed to be Geneva's liberties and freedoms was still lacking.

Alardet's mission obviously unsettled the seigneurie of Geneva. Under the cover provided by the clause in the perpetual treaty with Bern which prohibited Geneva from entering diplomatic negotiations without the canton's knowledge, the seigneurie sent an account of the Savoyard proposals to its combourgeois. The real motivation behind this despatch was somewhat different, for „Dans cette lettre perce l'appréhension que les Bernois, auprès desquels le duc avait entamé des tractations, ne se laissassent entraîner à perdre de vue les intérêts de Genève: „Nous voyons bien ... que les ambassadeurs de Savoie vont et viennent, mais nous avons envers MM de Berne bonne confiance qu'ils ne souffriront pas qu'il se façe quelquechose au préjudice de nostre Estat, comme aussi de nostre part, quelques entreprises, menaces, promesses et sollicitations qu'on nous façe, ils se peuvent asseurer de nostre loyauté et rondeur. “30

This was a timely move, as negotiations between Turin and Bern proceeded with much more purposefulness than the relatively tentative pourparlers between the duke and Geneva. A new phase was reached in November 1560 at a meeting at Neuchâtel during which the Savoyard delegation raised the issue of the legality of the alliance between Bern and Geneva, basing the argument on an earlier treaty between the House of Savoy and the canton which prohibited Bern from entering a combourgeoisie with either the subjects of the duke or those sovereignties enclaved within his lands. This suggestion neatly left open the question of to which of these categories Geneva belonged, but, with equal dexterity, introduced the problem of defining Geneva's legal status into the discussions surrounding the proposed accord between Savoy and Bern. The Council of Geneva noted on 10 December that „l'on reçoit missives de Messieurs de Berne ... contenant partie de leur départ de Neuchâtel de la journée y tenue avec les commis du duc de Savoie requérant leur fournir des droits, des libertés et franchises de cette cité par lesquelles ... on puisse défendre et répliquer contre lesdits de Savoie et montrer que nous avons pu nous allier avec les seig. bernois et par ce nous ont à bon droit défendre comme déjà en a été décidé par le fait de Payerne" ${ }^{\text {"31 }}$. There is at least a hint in the last phrase of this entry of the annoyance, soon to become undisguised irritation, which Geneva felt for its Bernese combourgeois over the canton's willingness to permit to be re-opened questions which, so Geneva posited, had been settled definitively by the sentence of Payerne. On 30 November 1530, the envoys of ten members of the Helvetic confederation, meeting at Payerne, issued a sentence which attempted to resolve the differences between Charles III of Savoy, on the one hand, and, on the other, Geneva, Bern and Fribourg. One critical element of this arbitral judgement was the recognition of the validity of Geneva's alliance of 1526 with the

${ }^{30}$ Roget, vol. VI, 6.

${ }^{31}$ AEG, R. C., vol. 56, fol. 115 r. 
canton of Bern. The duke's challenge to Geneva's legal competence to conclude any alliance without his consent had led to a series of armed encounters during the late 1520 s, and this section of the 1530 sentence of Payerne was treasured in Geneva as the foundation of the legitimacy of the seigneurie's independence of action. Whatever the constitutional position had been before 1530, the sentence of Payerne had, in the eyes of the Genevans, resolved a vital point which the seigneurie was determined need never be discussed again.

Bern's request for documentation placed Geneva in an awkward position. The seigneurie was eager to avoid a debate over rights and privileges dating from the period when political authority in the city had been shared among the prince-bishop, the duke of Savoy and the Councils. By discouraging Emanuele Filiberto's private diplomatic initiatives aimed at accommodation by negotiation between Geneva and Savoy, the seigneurie ran the risk of ducal application for cantonal arbitration, hoping that whatever claims Emanuele Filiberto put forward would be judged on the basis of those sentences and treaties which had anchored authority in the hands of the seigneurie. Instead, Geneva found itself subjected to pressure from Bern to justify its legal competence to conclude those very arrangements which had been the support for its exercise of power, detached from prince-bishop and duke, from the 1530 s. From 1560 on, adherence to the sentence of Payerne, with one major modification, became the keystone of Genevan policy, and the seigneurie strove to block any discussion of events which took place before the sentence of Payerne, even at the risk of antagonizing Bern by delaying the despatch of the requested documentation.

Behind the issue of the legality of the alliance between Bern and Geneva lurked unmistakably a threat to the seigneurie's exclusive exercise of authority within the city and the implication that this authority had been usurped from others who, at the very least, had a right in its share. Pierre Ronsard summed up the view of those who looked upon the events of the $1530 \mathrm{~s}$ as an illegal arrogation of power in the continuation to his Discours des misères de ce temps, published in 1562 and dedicated to Queen Catherine de' Medici:

Elle adonc en tirant sa parole contrainte,

Souspirant aigrement, me fit ainsi sa plainte:

„Une ville est assise és champs Savoysiens,

Qui par fraude a chassé ses Seigneurs anciens ..."32

Such interpretations were challenged by Calvin and Roset, who were members of a committee delegated to frame the Genevan response to Bern's request and to Savoy's challenge. „Que sur ce que les envoyés de Savoie avaient allégué, que les syndics et communauté de Genève, étant sujets de l'évêque, ne pouvaient s'engager par aucun traité, il était aisé de répondre qu'encore qu'il y eût peu de villes impériales sur lesquelles ou un évêque ou quelque prince voisin n'eût quelque droit, que cependant elles ne laissaient pas d'être estimées villes franches et libres, auxquelles il était permis

32 Pierre Ronsard, Oeuvres complètes, ed. G. Coben (Paris 1950: Bibliothèque de la Pléiade) vol. II, 557 , lines 24-27. 
de faire des alliances. ${ }^{\text {“33 }}$ This was not the first time that the definition of Geneva as a "free city" had made an appearance in the debate, for in 1560 the seigneurie, at the urging of Bern, appealed to the Diet of the Helvetic confederation, assembled at Baden, for some assurance that „une ville libre ne fût molestée“ and for assistance to „arrêter les projets que les ennemis de Genève pourraient former contre cette ville“34. The notion that Geneva possessed rights which were roughly equivalent to those of a Free Imperial City was promoted from time to time by the seigneurie and rested upon a simple acceptance of the events of 1536. Any investigation of rights and prerogatives before that date introduced the possibility of compensation not only for the duke of Savoy but also for the bishops of Geneva, who viewed themselves as exiled from their see and who had established themselves at Annecy, the capital of the apanage of Emanuele Filiberto's first cousin, Jacques of Savoy, duc de Nemours-Genevois ${ }^{35}$. Johannes Steiger, despatched from Bern to impress upon the seigneurie of Geneva the importance which the canton attached to the marshalling of convincing arguments to counter the Savoyard claims, met a pronounced reluctance to accept „notre besoin de revoquer en doute ce qui a été déterminé et passé en adjugé par les départs, même celui de Payerne, nous n'avons pas estimé qu'il fallut reproduire et mettre en avant ce qui a déjà été débattue et approuvé, mais qu'afin qu'on n'obmettre de faire ce que sera nécessaire ... on advisera faire tenir à ses supérieurs réponse par écrit et toutefois qu'on advise de ne se entremêler tellement qu'on y puisse avoir préjudice à l'avenir ${ }^{\text {“36. The }}$ Council „était dans la pensée qu'il valait beaucoup mieux de ne pas s'engager dans de longues contestations avec les Savoyards, et se borner à leur représenter en peu de mots les raisons pressantes que les seigneurs de Berne avaient de secourir leurs alliés de Genève en l'année $1536^{\text {“37 }}$. Such uncooperativeness produced deep frustration at Bern, for, as Jean-Antoine Gautier dryly observed, „Les seigneurs de Berne ne furent pas contents des éclaircissements qui furent données au seigneur Steiger." ${ }^{\text {(38 }}$

But at the same time that Geneva registered its profound misgivings about a compilation of a list of the seigneurie's rights and privileges, it also began to attack Emanuele Filiberto on those grounds which it thought likely the duke would use for the foundations of his claims. The validity of the application of the imperial vicariate of the dukes of Savoy to the city of Geneva was challenged ${ }^{39}$, and the ravages which Charles III's

${ }^{33}$ Gautier, vol. IV, 316.

${ }^{34}$ Ibid., vol. IV. 292.

${ }^{35}$ The bishop of Geneva from 1556 to 1568 was François de Bachod, whose position was complicated by the fact that from 1560 he was also the papal nuncio at Turin $(L$. Chevaillier, Les origines et les premières années de fonctionnement de la 'Nonciature de Savoie' à Turin (1560-1573), in: Etudes d'histoire du droit canonique dédiées à Gabriel Le Bras (Paris 1965) vol. I, 489-512).

${ }^{36}$ AEG, R. C., vol. 56, fol. 177 r.

${ }^{37}$ Gautier, vol. IV, 335.

${ }^{38}$ Ibid., vol. IV, 335.

${ }^{39}$ AEG, Affaires étrangères: Savoie, vol. IX contains an unpaginated Sommaire discours de prétentions des très illustres ducs de Savoie sur la ville franche et impériale de Genève. Although bound with documents dating from the 1560 s, some internal evidence suggests that it could have been written early in the reign (1580-1630) of Carlo Emanuele I, Emanuele Filiberto's son. It includes a meticulous attack upon Savoyard claims to the vicariate over Geneva and to the vidomnat. 
troops inflicted upon Genevan territory were introduced in the hope of countering any future pretentions of Emanuele Filiberto with a demand for war reparations. Until 1564, Geneva adhered to a policy of temporisation, discouraging any conference which would weigh the competing claims and stalling Bern's reiterated requests for documentation. A stalemate had developed in which Emanuele Filiberto only hinted at the extent of his claims and in which Geneva pointedly avoided any discussion which entailed a re-examination of its detachment from both duke and prince-bishop. Such stasis was complicated not only by the deepening misunderstanding within the combourgeoisie but also by the lack of knowledge in both Bern and Geneva about the intentions of one another. In 1562 the seigneurie of Geneva wrote to Bern that some time had passed since their ally had given them any information on the progress of the negotiations with Turin, and as late as 1564 the canton of Bern summed up its bewilderment with Genevan policy when, answering a request of opaque vagueness from the seigneurie for guidance in choosing a line of action, it observed that „ils avaient promis bailler avis, mais qu'il est à celui qui porte le soulier de savoir où il blesse“40. A further element of confusion derived from the perception, north of the Alps, of Savoyard policy, for Emanuele Filiberto was conducting a three-pronged campaign. The Savoy envoys entrusted with the Bernese negotiations continued to gnaw at the legality of the alliance between the canton and the seigneurie with all of its implications for a formal definition of Genevan sovereignty, based upon the comparison of rights and privileges dating from the fourteenth and fifteenth centuries. But at the same time that Savoy pursued this juridical approach to the problem, aimed at legal arbitration, the duke continued to launch informal initiatives directly to Geneva, without the participation of Bern, for a negotiated accommodation. In addition to both of these policies were the diplomatic manoeuvres in Rome and Madrid which initiated a sequence of rumours of incipient military action by the Catholic powers against Geneva. In this complex situation in which the motives, goals and policies of the individual parties were obscure and uncertain, the only progress to accord came from the tortuously slow and convoluted negotiations between Savoy and Bern, and as these crawled to a conclusion based upon the restitution to Emanuele Filiberto of some of the lands along Lake Geneva and near Geneva rather than within the Vaud heartland it became clear that the seigneurie could continue in its policy of temporisation only with growing difficulty.

In 1564-65 a significant effort to break this deadlock was made by Emanuele Filiberto, who sent another envoy to Geneva, and by his consort, Marguerite de France, who despatched two delegations to the city. Marguerite, generally believed to be at least sympathetic to the Reformation, occupied a unique position of respect in the worlds of both Catholics and Protestants. Writing to Renée de France, duchess of Ferrara, Calvin, shortly before his death, noted that ,J'ay entendu que Madame la duchesse de Savoie, vostre niepce, est en assez bon train, jusques à estre delibérée de se

40 AEG, R. C., vol. 59, vol. 39v. 
déclairer franchement ${ }^{\text {“4t }}$, a public profession which never took place. From the two approaches made by the duchess of Savoy and the mission of 1564 sent directly from the duke, which anticipated those of Marguerite by only a few months, emerges a coherent Savoyard programme for regulating relations between Geneva and Turin, many of the elements of which were familiar from Emanuele Filiberto's earlier proposals. According to Marguerite's emissaries, the duke had no intention of abridging Geneva's rights and franchises, nor of attempting to alter in any way the religious settlement. He intended to revive the Genevan fairs, the prosperity of which he would ensure by prohibiting his subjects from trading anywhere else. He would pay for the maintenance of a substantial garrison to protect the city, but the troops would be recruited by Geneva, the seigneurie submitting a list of three candidates from whom Emanuele Filiberto would select the commander. In return, the duke required recognition of his right to grant pardon, in his role as imperial vicar, and the succession to the vidomnat, which his ancestors had held ${ }^{42}$. But even on this last issue, the persistent and major obstacle to any accord between Geneva and Savoy, he was prepared to compromise and to limit his right to naming as his representative for the vidomnat in the city one of a list of three Genevan citizens proposed by the Council. The duke's own envoy also presented promises of non-interference in religious affairs and the demand for the vidomnat and other judicial privileges but stressed Emanuele Filiberto's eagerness for agreement, „puisqu'on pourrait bien en rebattre quelque chose, que c'était une affaire d'accommodement ${ }^{\text {*43 }}$. The duke asked to be received, accompanied only by his wife and his son, within Geneva, and „pour ce que entre autres points le droit de l'évêché lui semble le plus difficile à accorder, il se fait fort de la leur faire mettre entre leurs mains pour la bailler à qui bon le semblera ou bien d'en disposer à leur plaisir ... qu'ils [Savoy and Geneva] seraient maintenus en une paix perpétuelle, comme alliés et bons voisins, sans contrevenir à la confédération qu'ils ont avec les seigneurs de Berne, laquelle serait sans subjection, comme bons voisins et compagnons et serait la ville de Genève en plus grande autorité, étant maintenue par un tel prince "44. This was not the first time that Emanuele Filiberto had shown himself prepared to ignore the rights of the exiled bishop of Geneva, for Roset reported a 1562 tentative which included the duke „déclarans qu'il n'entendoit attenter à la religion, ny à la restitution de l'évesque ${ }^{\text {«45 }}$. Enshrined as they were within a comprehensive programme, the 1564 proposals regarding the bishopric made a greater impact. Finally, to put the collective mind at rest on the question of Savoyard goodwill, the duke consistently proposed two, sometimes three, guarantors to any agreement chosen from among the German Protestant princes, most frequently the Elector Palatine and the duke of Württemberg.

\footnotetext{
${ }^{41}$ Lettres de Jean Calvin: Lettres françaises, ed. J. Bonnet (Paris 1854) vol. II, 559. The letter to the Duchess Renée is dated 4 April 1564; Calvin died on 27 May.

${ }^{42}$ [T. Heyer], Marguerite de France, duchesse de Savoie, ses rapports avec Genève, in: Mémoires et documents de la Société d'histoire et d'archéologie de Genève XV (1864) 122-144.

43 Gautier, vol. IV, 453.

44 AEG, Pièces historiques, no. 1771.

${ }^{45}$ Raset, 448: C. 72.
} 
Viewed as a whole, these proposals were taken seriously enough in Geneva for special commissions to be established to scrutinize the implications, but in each instance the suggestions emanating from the court of Turin were declined with firm politeness, ostensibly because of the exclusive nature of the agreements with Bern. There were, however, two further, potent reasons behind their rejection. In the first place, the sequence of projects put forward by the agents of Emanuele Filiberto and Marguerite left no room for a recognition of the outright sovereignty of the seigneurie. The duke's proposals amounted to a return to the mixed sovereignty of pre-revolutionary Geneva, with the modification that the prince-bishop was excluded from the political equation, the tidiest way of solving the potentially thorny problem of the ownership of ecclesiastical property and an absolutely vital condition for the preservation of the reformation settlement which Emanuele Filiberto promised to leave untouched. Even this objection might, just conceivably, have been circumvented had fear and distrust not played such major roles. A 1563 approach from the court of Turin had been dismissed with the observation that the duke's agent „ne voudrait que la ruine de Genève et chercher à nous déjoindre d'avec nos combourgeois “46. Gautier elaborated on this attitude in his analysis of the Genevan position: the seigneurie „avaient trouvé dans cette proposition de très grands inconvéniens, et qui ne manqueraient point d'entraîner la ruine totale de la République, étant dans la pensée, comme ils l'étaient, que si l'on accordait quelque avantage ou quelque prérogative au duc de Savoie en Genève, pour petite qu'elle fût, il se rendrait, avec le temps, infailliblement le maître absolu de cette ville $^{\text {“47 }}$. There could be no concessions on the vidomnat, for, as a Genevan summary of Savoyard pretentions, possibly of a later date, put it, „Le vidomnat ... n'a jamais été ni est aujourd'hui prétendu par les ducs de Savoie sinon pour s'en servir comme d'un étrier pour monter dans la selle." ${ }^{\text {cs8 }}$ It should be stressed that these informal approaches to Geneva coincided with Turin's public demands for an arbitrational judgement on the seigneurie's legal right to contract the alliance with Bern, but the disappointing reactions to these proposals did not cause Emanuele Filiberto to abandon this line of policy entirely. As late as 1569 , on the eve of the conclusion of the mode de vitre, Hélène de Tournon, comtesse de Montrevel, the Protestant co-gouvernante of the young prince of Piedmont, the future Duke Carlo Emanuele I, paid a private visit to Geneva during which she approached Roset about a negotiated accommodation between her sovereign and the seigneurie.

The proposals of $1564-65$ were, to that date, the most elaborated and detailed statement of the formula which Emanuele Filiberto was prepared to accept. In declining propositions which, to Savoyard eyes, conceded a great deal, the seigneurie of Geneva went to considerable lengths to avoid offending the Duchess Marguerite, who had instigated some of the approaches and who had held out to the Council of Geneva the hope of securing some form of toleration for the Calvinists in Piedmont. Théodore de Bèze wrote to Marguerite in February 1565 and appealed again to the notion of Ge-

${ }^{46}$ AEG, R. C., vol. 58, fol. $66 \mathrm{v}$.

47 Gautier, vol. IV, 502-503.

48 AEG, Affaires étrangères: Savoie, vol. IX, Sommaire discours ... See note 39 above. 
neva as a free city: „Et de fait, aussy, ce n'est point chose nouvelle ni dérogeante à la grandeur d'un prince, d'avoir des villes impériales et franches, voire quelquefoys au milieu de leurs pays, comme il se peult veoir estre praticqué en toutes les principaultés d'Allemagne." De Bèze also referred to the respect that the seigneurie had for Emanuele Filiberto and for Marguerite, but mentioned as well „le désir qu'ils ont de vivre en paix en leur petit Estat ${ }^{\text {“49 }}$. As summarized by de Bèze, the position of Geneva, and the rhetoric in which it was expressed, had altered very little in the six years since the Treaty of Cateau-Cambrésis.

The only peaceful alternative to a direct accommodation with Emanuele Filiberto was a legal arbitration under the aegis of the Helvetic confederation. Such a course of action necessitated, however, the presentation of the written rights and privileges of the seigneurie of Geneva and their comparison with the contesting claims of the House of Savoy, the very documentary confrontation the Genevans had attempted to avoid when pressed by Bern to assemble the archival support for the possession of exclusive sovereignty. The conference at Lausanne in October 1564 seems to have been the first attempt to clarify the positions of both Turin and Geneva by bringing together envoys of both the duke and the seigneurie for a joint meeting, but even then the reluctance of the city to define its claims was manifest. Montfort, one of the Savoyard delegation, addressed the Genevans and „les invita à s'expliquer sur les prétentions de leurs supérieurs, ce que Roset et ses collègues ne voulurent pas faire, mais le prièrent de s'ouvre lui-même, le premier, sur les intentions de son Altesse de Savoie ..." ${ }^{\text {so }}$. The Savoyard envoys were prepared to promise that Emanuele Filiberto aimed at no change in the liberties or the religious settlement of Geneva, but insisted upon the vidomnat for the duke. The vidomnat and, attached to it, the recognition of Emanuele Filiberto as imperial vicar by the seigneurie, was the issue which the House of Savoy was not prepared to concede; moreover, the Savoyard delegation to Lausanne was under instructions not to proceed to any further discussions until the question of the vidomnat had been settled. At this point the balance within the negotiations shifted dramatically, for the public statement and clarification of Emanuele Filiberto's claims provided the target, previously absent, for Genevan diplomatic activity. Both the vidomnat and the imperial vicariate led directly to ultimate appellate jurisdiction, and both positions attributed to themselves some elements of the right of pardon, widely viewed in early-modern Europe as a regalian privilege, an aspect of sovereignty. Once Emanuele Filiberto's pretentions were clear, the seigneurie was able to assemble its own case, one presented primarily as demolishing the duke's claims rather than establishing those of the city.

The seigneurie of Geneva faced serious practical difficulties in collecting its documentation. In the first place, the city was not in possession of all of its archives. Over forty pieces presented at the 1530 adjudication at Payerne had been deposited, for safety's sake, with the Catholic canton of Fribourg, at that time bound with Bern in the combourgeoisie with Geneva. But Fribourg had withdrawn from the combourgeoisie in

19. Heyer, Marguerite de France, 139.

so Gautier, vol. IV, 467. 
1533, and the documents had never been returned. Roset was sent to Fribourg in September 1564 to request their restitution and was informed that although some pieces, including Council registers and the livre des franchises, would be returned, another dozen touching diocesan authority could not. The Fribourg councils ,ne pouvaient pas remettre lesdits droits sans le consentement de l'évêque qui y avait mis empêchement et pourtant n'en pouvaient point délivrer de ceux qui lui attouchaient sans en avoir premièrement ouï le bon vouloir des sieurs du chapitre et des chanoines, auxquels pour cet effet ils en écriraient“ ${ }^{\text {s1 }}$. The Genevan delegation was permitted, however, to make copies of these withheld papers and was asked by the canton of Fribourg if „Messieurs de Genève voudraient se battre pour lesdits droits avec lesdits chanoines " 52 . This unwelcome reminder of the rights belonging to the bishop seems not to have been pursued, and it was not until 1581 that the original versions of these documents were returned to Geneva ${ }^{53}$. Michel Roset's presentation, in June 1562, of his Chroniques to the seigneurie may have reflected Genevan consciousness of the inadequacy of the city's archives for diplomatic purposes. The register of the Council observed that the aim of Roset's „recueil et sommaire des choses concernantes la ville de Genève dès sa fondation jusques au mois de mai dernièrement passé" was to ensure that „du contenu d'icelui chacun soit informé et n'en soit ignorant et non seulement nous, mais aussi nos successeurs ..." ${ }^{\text {" }}$.

The development of a coherent Genevan answer to Emanuele Filiberto's claims can be discerned in the instructions given by the seigneurie to their envoys who attended, most frequently as observers, the Diets of the Helvetic confederation or the negotiations between Bern and Savoy. The most difficult problem was posed by the sentence of Payerne, which had validated Geneva's combourgeoisie with Bern and to which the seigneurie had clung as the justification of its possession of exclusive sovereign authority. The sentence of Payerne, however, had also accorded the vidomnat to the duke of Savoy, but, according to the Genevan position, „en termes exprès que c'était sans préjudice des libertés de Genève et du droit que l'évêque avait sur cet office, et à condition que ce prince et ses officiers n'exerçassent aucune vengeance contre les Genevois à l'occasion des choses passées et qu'ils ne leur fissent aucune violence, ni en général, ni en particulier, de quoi il devait donner de bonnes assurances, pour lui et pour ses successeurs, avant que d'être remis en possession ..." “55. Duke Charles III's economic blockade of Geneva during the early 1530s, that is, after the sentence of Payerne of 1530 , followed by „une infinité de violences exercées en Savoie contre les Genevois qui allaient et venaient dans le pays" 56 and two years of war signified Charles's rupture of the sentence of Payerne and his forfeiture, for himself and his descendants, of the

\footnotetext{
51 AEG, R. C., vol. 59, fol. $117 \mathrm{r}$.

${ }^{52}$ AEG, R. C., vol. 59, fol. $117 \mathrm{v}$.

${ }^{33}$ Louis Sordet, Recherches au sujet des titres remis à la garde de Messieurs de Fribourg après la journée de Payerne, in: Mémoires et documents de la Société d'histoire et d'archéologie de Genève IV (1844) 133, 136.

${ }^{34}$ Roset, vi.

${ }^{55}$ Gautier, vol. IV, 389.

56 Ibid., vol. IV, 390.
} 
vidomnat: „Que par toutes ces raisons, il paraissait que la ville de Genève avait possédé, depuis, c'est-à-dire depuis trente et un ans, le vidomnat à juste titre."57

Although this argument became a fixture of Genevan public policy, it would seem that the seigneurie was not entirely comfortable with a justification based on actions which they alone had judged as constituting a forfeiture and which leaned heavily upon whatever rights could be extracted from over thirty years of tenure in a position which others viewed as having been usurped from its legal occupant. In 1564, Geneva approached Bern with a request that the vidomnat be treated as an object assigned by Bern to Geneva in the wake of Charles III's defeat and be guaranteed by the canton in the forthcoming treaty between Bern and Savoy. Bern refused to give any assurance to Geneva on the possession of the vidomnat, and the seigneurie had to content itself with its claim to the contested office because ,à tort et sans cause le feu duc de Savoie avait molesté par longues guerres et violences une ville de Genève, prétendant y avoir droits de souverain, ce qu'il n'avait eus jamais “58. Closely linked to this reasoning were the growing Genevan claims for reparations from Emanuele Filiberto for the financial chaos his father's policies had produced in the city.

The challenge to Emanuele Filiberto's claim to exercise the imperial vicariate within Geneva was based upon a revocation by the very Emperor, Charles IV, who had confirmed Count Amadeus VI in the vicariate in 1356; even if it was accepted that the duke of Savoy was imperial vicar, a series of exemptions was strung together to prove that the city had consistently been viewed by successive Emperors as detached from Savoyard jurisdiction. Lest the rights of the bishop of Geneva be pressed, the envoys of Geneva were instructed to cite the tenure of the last resident incumbent, Pierre de La Baume: „au lieu d'en agir en père et pasteur du peuple, il en devient ennemi, et, en cette qualité, il se trouva lui-même en personne devant Genève avec l'armée de Savoie le 30 juillet 1534 ... quoique ce prélat eût été plusieurs fois prié de la part des citoyens, tant par lettres que par députés, de revenir dans Genève pour la défendre contre son ennemi, selon son devoir et son serment, au préjudice duquel il avait continué d'exercer diverses hostilités ... Il s'était vu légitimement privé de l'autorité qu'il y avait auparavant, laquelle n'avait été accordée dans son origine, à ses prédécesseurs qu'à condition qu'ils seraient protecteurs des libertés du peuple."59 As with the duke and the vidomnat, the notion of forfeiture was adopted by the seigneurie as a reply to any episcopal claims, and the rhetoric of broken enthronement oaths and the original institution of authority based upon the protection of the liberties of the people moved the Council, wittingly or not, close to the contract theory of government.

All of these arguments were essentially negative in character. It is difficult to find in the mass of political and diplomatic correspondence dating from the 1560 s an elaboration of Geneva's positive claims to sovereignty which is as clear and as emphatic as its assertions that the House of Savoy had been stripped of its rights and privileges because of criminal acts. Instead, the seigneurie seems to have attempted to avoid a pre-

57 Ibid., vol. IV, 390.

${ }^{58}$ AEG, R. C., vol. 58, fol. $124 \mathrm{v}$.

39 Gautier, vol. IV, 394-395. 
cise definition of the nature of the Genevan state. The model of a Free Imperial City, or, at least, a free city was appealed to with regular although not demonstrative persistence. Emanuele Filiberto's pretentions to the imperial vicariate may have encouraged some within Geneva to address themselves to the city's own relationship with the Empire. One set of diplomatic instructions dating from 1564 pointed out that "cette ville n'avait jamais eu, par le passé, d'autre prince que son évêque, et qu'elle avait, pour lors, son honorable magistrat, comme la chose paraissait clairement par plusieurs bulles impériales et papales ${ }^{~} 60$, a characteristically vague summary of Geneva's constitutional position and one which appealed to imperial recognition for support. Throughout the 1560 s the formula which described Geneva as a "ville franche et impériale“ endowed with privileges dating back to the reign of Frederick Barbarossa was employed to dispute Emanuele Filiberto's claims to exercise the imperial vicariate in Geneva. The seigneurie could not recognize the duke's ultimate appellate jurisdiction „parce qu'ils ne pouvaient céder le droit de l'Empereur" ${ }^{\text {"61 }}$. An appeal for support addressed to Friedrich III, the Elector Palatine, depicted Geneva „se voyant à la veille de perdre les libertés et les privilèges impériaux qui lui avaient été accordés depuis plusieurs siècles“ and solicited the protection it was hoped he would bestow in his role as first elector of the Empire ${ }^{62}$. The Elector Palatine was presented with a „Bref mémoire pour entendre que le duc de Savoie est mal fondé dans ses prétentes contre la cité de Genève“ which began with the observation that „Genève était cité franche et impériale fort longtemps avant que le prince Béral, duquel les illustres princes de Savoie se disent issus fût venu en ces pays “"63. Letters from the Emperor Charles V, who feared a Bernese coup in Geneva in the 1530s and 1540s, were turned against his nephew: in 1540 the Emperor had ordered Geneva to „demeurer dans l'obéissance de l'Empire, comme formant une ville impériale ${ }^{\text {"64 }}$. William Monter has drawn attention to the survival of imperial iconography in Geneva and cites the inclusion of the Habsburg eagle on stained-glass heraldic devices. One such window, dating from 1547, combines the imperial eagle with the motto of the Genevan reformers, „Post tenebras lux ${ }^{665}$.

Identification with the traditions and privileges of Free Imperial Cities was not without its problems, however, for the bishop of Geneva was a prince of the Empire. To deal with the contradiction, the seigneurie had to rely upon Pierre de La Baume's 'forfeiture'; as one Genevan delegation replied, in 1565, to a Savoyard observation that the imperial privileges had been granted to the bishop and not to the city, „leurs supérieurs étaient en place de l'évêque ${ }^{\text {" } 66}$. This interpretation of the events of the 1530 s did not find universal acceptance, and the more frequently Geneva resorted to a recitation of its privileges as an imperial city, the greater became the potential for intervention from Vienna. This dilemma may have been at the root of the decision to appeal to

${ }^{60}$ Ibid., vol. IV, 470.

61 Ibid., vol. IV, 502.

${ }^{62}$ Ibid., vol. IV, 509.

${ }^{63}$ AEG, Copies de lettres, vol. VII, fol. 272.

${ }^{64}$ Gautier, vol. IV, 393.

${ }^{65}$ Monter, Calvin's Geneva, 78.

${ }^{66}$ Gautier, vol. IV, 493. 
the Elector Friedrich III to use his good offices in Geneva's favour at the imperial court shortly after the accession in 1564 of Maximilian II. The elector was asked to evaluate the possibilities that Geneva ,pût obtenir de l'empereur la confirmation de son gouvernement présent et une déclaration qu'elle avait acquis légitimement tout le droit qu'avait l'évêque ${ }^{\text {667. }}$.

But although Friedrich was enthusiastic about this proposal, there is no evidence that the Genevans took the matter further. When, in 1571, Zurkinden suggested to de Bèze that the differences between Savoy and Geneva be submitted to Vienna, de Bèze replied that he could see no hope of such a procedure succeeding ${ }^{68}$.

The seigneurie seems to have aimed at having the enjoyment of the privileges of a Free Imperial City without being directly responsible to the Emperor, and for this reason the nature of the relationship with Vienna was kept as vague as possible in those documents which dealt with the rights deriving from imperial bulls. When the question of ultimate sovereignty was raised, inevitable in any discussion of Geneva's membership in the Empire, the seigneurie could take refuge, as it had with Alardet, in the myth that such power belonged to God, a pose which echoed the 1544 reply to Fribourg "que en Genesve il ny a aultre evesque que Dieu“699.

The concept of Geneva as a republic was, in the 1560 s, even more shadowy than its presentation as a Free Imperial City. Alardet's temper must have been very frayed during his mission late in 1559 when he replied to Genevan excuses, „Mais si vous êtes si petits que vous dites, pourquoi est-ce que dans toutes vos écritures et lettres, tant patentes que missives, vous usez de termes si hauts et de titres si brillants que la république romaine n'en prit jamais de plus superbes? ${ }^{470}$ The registers of the Council and the diplomatic correspondence of this decade, however, do not support the high level of republican consciousness which Alardet's outburst suggests. The situation, furthermore, has been muddied by the frequency with which historians of Geneva living in the eighteenth, nineteenth and twentieth centuries have touched upon the republican theme in their commentaries. When Alardet remonstrated with the seigneurie for its failure to despatch a delegation carrying congratulations to Emanuele Filiberto on his return to his domains, he noted, according to his own account, „Quand mon susdit seigneur est revenu en ses Etats, la seigneurie de Venise et celle de Gênes l'ont mandé visiter par ambassadeurs se congratulant avec lui de son heureux retour."71 Arturo Segre published an Italian version of Alardet's account of his mission which gave a fuller list: „Quand'egli giunse a Lione per fare ritorno nei suoi Stati, ambasciatori di Venezia, Genova, Firenze, Ferrara, Mantova, Urbino gli fecero visita, e voi, cosí vicini,

${ }^{67}$ Ibid., vol. IV, 510.

${ }^{68}$ This letter will appear as no. 859 in the forthcoming 1571 volume of the Correspondance de Théodore de Bèze (Geneva 1970- ). I am grateful to Alain Dufour, who, with the aid of Mario Turchetti, drew my attention to this passage.

69 Sordet, Recherches au sujet des titres, 131.

${ }^{70}$ Gaberel, Une escalade diplomatique, 587.

${ }^{11}$ Ibid., 584. 
con poca cortesia, anzi con errore manifesto vi siete astenuti! " 72 The register of the Council, however, recorded „Que d'autres notables républiques, comme Venise, Gênes et autres lui ont envoyé ambassadeurs pour lui congratuler ${ }^{673}$. But in compiling his Chroniques, Michel Roset, who may have been present at this meeting, wrote only of Emanuele Filiberto, „qui pouvait trouver estrange que Genève n'eust point envoyé à luy, comme avoient faict plusieurs grandes citez" 74 . Jean-Antoine Gautier, writing in the first years of the eighteenth century, adopted for his account: „diverses républiques considérables, comme Venise et Gênes, l'avaient fait féliciter." ${ }^{\text {"75 }}$ One discourse, obviously, could be remembered in different ways, but it is striking that the account of Alardet's speech provides one of the rare instances of the word 'republic' appearing in the register. More frequently, 'seigneurie' or 'ville' or 'cité' were used, even though Gautier's otherwise exemplary paraphrases often render them all homogeneously as 'republic'. The flattering comparison with Venice and Genoa did not, moreover, introduce a theme of republican identity into the political discussions of the Genevan seigneurie, and such contemporary reticence is, perhaps, even more noteworthy given the large number of émigrés welcomed in Geneva from the Republic of Lucca. Certainly, there are some references to Geneva as a republic. Théodore de Bèze, writing to Marguerite de France, cited „l'affection sincère qu'il plaira à Votre Altesse porter à ceste République ${ }^{\text {"76 }}$ and Michel Roset reported, from a visit to Zürich, „des propos désobligeants sur M. Calvin, disant qu'il était comme un second pape, que notre république était pleine de mutineries, de séditions ${ }^{477}$. But these stray references seem not to have been embroidered upon in the 1560 s, even at a time when Geneva was under pressure to forge a convincing reply to the dynastic claims of Emanuele Filiberto. Evidence for a developed consciousness of the distinctions between republican and princely forms of government is thin. Gautier recounts that, following the duke's proposal of trusted German Protestant princes as guarantors of any agreement, it was observed in Geneva that „il était naturel de [les] soupçonner d'être portés à favoriser un autre prince, au préjudice d'une république“78. Such worries did not, however, discourage the seigneurie from approaching the Elector Palatine, one of the princes specifically suggested by the emissaries of Savoy, in the very next year ${ }^{79}$, nor did fears of princely collusion halt letters about Genevan sovereignty to Charles IX ${ }^{80}$ and tentatives to Catherine de' Medici exploring the possibility of Geneva's inclusion in an alliance between France and Bern ${ }^{81}$. Henri Fazy's enthusiasm for "la conception de la cité

${ }^{2}$ Arturo Segre, Riacquisto e ingrandimento dei domini (politica estera), Emanuele Filiberto (Turin 1928) 108. Unfortunately, Segre does not give a reference for this document.

${ }^{73}$ AEG, R. C., vol. 55, fol. $164 \mathrm{r}$.

${ }^{4}$ Roset, 433-434: C. 52 bis.

75 Gautier, vol. IV, 282.

${ }^{16}$ Heyer, Marguerite de France, 139.

77 AEG, Pièces historiques, no. 1707.

${ }^{78}$ Gautier, vol. IV, 455.

${ }^{79}$ AEG, Copies de lettres, vol. VII, fols. 270-271.

${ }^{80}$ AEG, Copies de lettres, vol. VII, fol. 243.

${ }^{81}$ AEG, Extraits des registres: Affaires étrangères, vol. II, fols. 944-945. 
antique ... encore toute puissante; le citoyen, le magistrat appartenaient corps et âme à la République ${ }^{\text {“82 }}$ reads more as an effusion of nineteenth-century parliamentary democracy, appearing, as it does, in the introduction to his edition of Roset's Chroniques, a work which avoids any discussion about republicanism or even the nature of the Genevan government. Given such reticence, it is easier to accept Alain Dufour's view that there was, in the political as opposed to the religious sphere, „Rien chez eux de comparable aux assemblées de la première République française, qui se savaient exemple offert au monde ${ }^{\text {"83 }}$.

Obviously there were some elements of a republican ideology in Geneva during the 1560s, as there were of the theory that the city formed, or should form, part of the Holy Roman Empire and enjoy the privileges of a Free Imperial City. These were two distinct strands, neither of which developed at this period because the goal of the seigneurie to achieve recognition of its sovereignty on the basis of the simple acceptance of the sentence of Payerne precluded, by necessity, a precise and meticulous definition of the component parts of the Genevan polity. Dufour has drawn a clear distinction between the publishing efforts of the directors of the Genevan reformation and those of the members of the Genevan seigneurie, a division not infrequently ignored by commentators who have elided the religious history and the political history of the city into one. „Les ,ordonnances sur la réformation', c'est-à-dire l'organisation ecclésiastique de Genève, les règlements du Collège et de l'Académie, les ordonnances somptuaires, connurent la publicité de l'imprimerie à plusieurs reprises, dès le temps de Calvin, car en ces questions prévalait l'influence de la Compagnie des pasteurs et son chef, presque tous hommes de Refuge, fort conscients du rôle d'exemple que leur église avait à assumer. Mais les ,édits civils' qui concernaient l'organisation de l'Etat ... restèrent pendant des siècles à l'état des manuscrits; on les portait à la connaissance du peuple par le moyen des crieurs publics. "Bi The single exception to this silence was published in London in 1562, The Lawes and Statutes of Geneva, „translated out of Frenche into Englishe by Robert Fills ${ }^{485}$ and dedicated to Queen Elizabeth's favourite, Robert Dudley, earl of Leicester. Fills appears to have emigrated to Geneva, most probably during the reign of Mary I, and he claimed the acquaintance of Théodore de Bèze ${ }^{86}$, which supports the authenticity of the translation of the documents he procured. Fills's book is exclusively procedural, a compendium of laws and custom rather than a constitutional analysis of the state. The very word 'republic' does not make an appearance. Instead there are legal injunctions not ,to alienate, transport or change in any manner of wise, the senorie and principalitie and state of Geneva, otherwise than God hath ordeyned it $^{\text {“87 }}$ and expressions of concern for "the greater advauncement of

\footnotetext{
82 Roset, XXIV.

${ }^{83}$ Alain Dufour, Le mythe de Genève au temps de Calvin, in: Histoire politique et psychologie historique (Geneva 1966) 80.

84 Ibid., 81.

${ }^{85}$ Robert Fills, The Lawes and Statutes of Geneva (London 1562) title page.

${ }^{86}$ Dictionary of National Biography, vol. XVIII (London 1889) 440.

${ }^{87}$ Fills, The Lawes and Statutes, $70 \mathrm{v}$.
} 
this commonwealth and principalitie ${ }^{\text {(88. }}$. When Fills needed to make a distinction between the state and the government, he turned to the concepts of principality and seigneurie respectively: ,if any do percyve any maner of conspiracie or practise against the sayde principalitie ... he ought and is bounde to come incontinent to the Senorie ..." ${ }^{* 9}$. The claims of the House of Savoy and the pressure from Bern had produced a refinement in the archival and legalistic sophistication of the seigneurie of Geneva, but its basic position remained unchanged during the 1560s: „il leur semblait, pour éviter tous les inconvéniens, il vaudrait mieux, sans entrer dans un si grand détail, que le traité [proposal of 1564] portât en général qu'on laisserait la ville de Genève dans la situation où elle était par rapport à son gouvernement, à ses franchises, au commerce, au droit de tirer des vivres de Savoie et à la religion."90

The seigneurie continued to adhere to this position even after 1567, when Emanuele Filiberto resumed possession of the bailliages of Gex, Ternier and Gailliard and of the Chablais. The interpenetration of Savoyard affairs with Genevan affairs thickened to become a dense mass of overlapping and contested jurisdictions; the provisioning of Geneva, always a problem, assumed the aspect of an element of Emanuele Filiberto's state policy. Savoyard lands, as a result of the restitution, surrounded a city in which the duke claimed specific juridical rights; the free flow of foodstuffs into Geneva and the integrity of the possessions belonging to Genevan citizens in lands which had been restored to the duke became the most obvious political powderkegs which economic embargoes imposed from Turin and armed skirmishes between Savoyards and Genevans threatened to ignite. Bern was especially exercised by the nightmare vision of a repetition of the events of 1536 , one in which a confrontation between the seigneurie and the duke would explode into a transalpine war which would divide the Helvetic confederation along confessional lines. As Geneva had consistently rebuffed all of Emanuele Filiberto's tentatives for a negotiated accommodation and as it seemed impossible to devise a mechanism of legal arbitration which both parties would accept as binding, Bern turned to the solution of a mode de vivre which would freeze all questions of sovereignty for over two decades and restore tranquillity to the lands around Lake Geneva.

Bern's proposals were accepted by both Emanuele Filberto and the seigneurie of Geneva in 1570 , but the ratification of the agreement demonstrated that the sovereignty disputes which had animated the relations of Savoy, Geneva and Bern since the Treaty of Cateau-Cambrésis were far from resolved. Emanuele Filiberto's ratification qualified him as count of Geneva and referred not to the 'ville de Genève' but to 'ceux de Genève', taken to imply that the citizens of the city were Savoyard subjects. This wording was absent from the original draft of the mode de vivre. The Genevans were reluctant to break the accord on these grounds alone, „puisque les plus grands princes ne se faisaient pas de peine d'en voir d'autres prendre leurs titres, comme le roi de France qui souffrait que celui d'Angleterre s'appelât roi de France et dans ses lettres et

\footnotetext{
88 Ibid., $76 \mathrm{v}$.

89 Ibid., 70v-71 r.

90 Gautier, vol. IV, 447.
} 
dans ses traités ..." ${ }^{\text {11 }}$. Bern advised that it was sufficient that the duke had not been styled Count of Geneva in the original draft of the agreement, and the Genevans took the additional precaution of inserting in their ratification a protest against Emanuele Filiberto's action „en se nommant comte de Genève, ce qu'à l'avenir pourrait être tiré en conséquence contre nous, notre état et droit de souveraineté, si nous avons nuement et simplement accepté lesdites ratifications en la qualité qu'elles sont dressées ${ }^{\text {(492 }}$. Instead, they returned to the original draft, which „[nous] avons de notre certaine science et volonté approuvé, ratifié et homologué, [et nous] approuvons, ratifions et homologuons ledit traité et moyen de vivre et tout son contenu de mot à mot"93. No progress had been made in defining the legal relationship between the city of Geneva and the House of Savoy. During succeeding decades the Dukes of Savoy continued to apply a policy of public menace mixed with private conciliation which was rejected consistently by a seigneurie which saw the maintenance of Geneva's independence and the preservation of the reformation settlement as absolutely reliant upon the monopoly of sovereignty with which it had been endowed by the advantageous conjuncture of events in 1536. In its efforts to avoid „le moindre changement à l'état et au gouvernement de leur ville ${ }^{\text {"94 }}$ the seigneurie continued to place greater faith in the outright and tenaciously defended possession of sovereignty than in the evolution of an elaborate formula of rights and privileges which would have defined the nature of the state.

${ }^{91}$ Ibid., vol. V, 59.

92 AEG, Pièces historiques, no. 1890.

${ }^{93}$ AEG, Pièces historiques, no. 1890.

94 Gautier, vol. IV, 389. 
